\title{
Salmonella Serotype Group C1
}

National Cancer Institute

\section{Source}

National Cancer Institute. Salmonella Serotype Group C1. NCI Thesaurus. Code C124382.

Characterization of salmonella bacteria subspecies as serotype group C1 based on the specific immunologic reactivity of cell surface lipopolysaccharide-protein chains called $O$ antigens. 